\title{
Relocation of geological survey 'could free funds for scientists'
}

[WASHINGTON] Fears that a lack of money to hire young scientists is draining the US Geological Survey (USGS) of its intellectual vitality lie behind an instruction to prepare for the relocation of the agency's western headquarters from Menlo Park, California, to a site outside the San Francisco Bay area, claims a senior survey official.

A directive from the interior secretary, Bruce Babbitt, asked the USGS to vacate two buildings in Menlo Park, Silicon Valley, and to carry out a speedy review of the costs and consequences of moving most or all of its 810 staff from the site, where $\$ 14$ million of the $\$ 80$ million budget is being paid in rent.

Babbitt's request for the review stemmed from his desire to spend money on "building the intellectual capital of the organization", rather than on ever-increasing rents, says Tom Casadevall, the survey's western regional director.

The issue of high costs at Menlo Park is not new: in the early 1980s, the survey's national mapping and water resources divisions decided to move staff to other locations. As a result of relocations and retirements, these two divisions now have about 250 fewer people at Menlo Park than in 1982.

Apart from the high rent bill, $\$ 50$ million of the total Menlo Park budget of $\$ 80$ million is spent on salaries. "This doesn't leave a lot for equipment, fieldwork and so on," says George Hargrove, acting chief of programme support for the western region. A recent rent increase was "an indication of what direction we're headed. When you have overhead eating into the operating budget, alarm bells go off".

Scientists at Menlo Park were stunned by

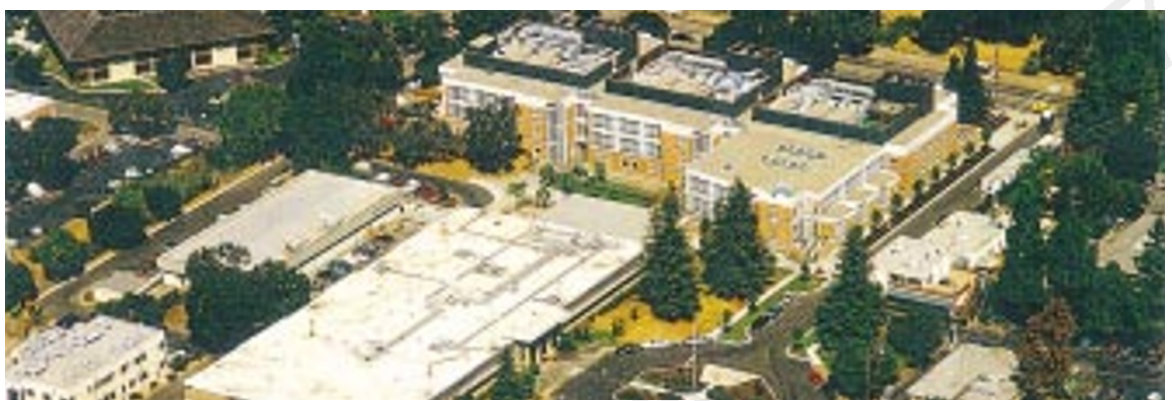

Seismic shift? The USGS has been asked to plan for the relocation of most activities from Menlo Park.

the suddenness of the request, however. It was conveyed to Casadevall in a memorandum from Gordon Eaton, director of the USGS, released to staff on 25 August and then leaked to the press. As well as demanding a review and "preliminary action plan" by 25 September, Eaton asks for the immediate cancellation of all lease renewals at Menlo Park, and for two buildings (7 and 8) to be vacated within a year. The memorandum sets a five-year timescale for relocating all or most of the other Menlo Park activities.

Buildings 7 and 8 are occupied by the survey's 260-strong earthquake hazards team, together with some other staff. The buildings are leased from a private company, which tried to increase the annual rent from $\$ 2.5$ million to more than $\$ 4$ million when the lease expired in June.

Casadevall is trying to reassure his colleagues that the dates mentioned are for guidance only, and are not inviolable. They are "intended to impart a sense of urgency", he says. Casadevall adds that some people will not work at Menlo Park because of local house prices. The interior department's

\section{Exonerated researcher settles for $\mathbf{\$ 3} \mathbf{m}$}

[WASHINGTON] Bernard Fisher, a cancer researcher at the University of Pittsburgh who sued after he was dismissed and falsely accused of scientific misconduct, has won $\$ 2.75$ million in damages and an apology from the university. The National Cancer Institute (NCI) will pay $\$ 300,000$ towards his legal fees as part of the settlement.

The agreement ends a battle that began in 1994, when the government charged Fisher with scientific misconduct and the NCI removed him from his job as head of a major breast cancer study. The case was highlighted by hearings held in the US Congress at the time by Representative John Dingell (Democrat, Michigan) (see Nature 368,679 ; 1994).
Fisher sued the government and the university, arguing that his constitutional rights to due process and scientific freedom had been violated. In February he was exonerated by government investigators of charges that he knowingly published research containing falsified data. The settlement of Fisher's suit, which was to have gone to trial on Tuesday (2 September), was announced by Fisher and the University of Pittsburgh last week.

Fisher, who is 78, said he was "pleased and satisfied" by the settlement. "It was really done for all scientists and not just for me, because the kinds of things that happened to me, all other scientists are vulnerable to," he says.

Meredith Wadman main desire, he says, is to attract more young scientists. "The mean age of [scientists in] the geologic division is 54," he says.

But, whereas Casadevall says that a move to lower-cost premises would release money for building the survey's "intellectual capital", others see a move out of the Bay area as a hazard to its intellectual health. Some worry about the practicality of scientists moving their families, while others cite the usefulness of close collaboration with university scientists at Stanford and Berkeley, and with state and federal agencies in the Bay area. Also, activities such as the earthquake hazards reduction programme and the San Francisco Bay and Delta ecosystem programme use the area itself as a natural laboratory.

Babbitt is said to favour a move to Sacramento, where other parts of the interior department have offices, or to Davis, its neighbouring university town. Having removed scientists from the other branches of the interior department to form the National Biological Service - now the Biological Resources Division of the USGS Babbitt believes that the USGS should serve as a "science service agency" for its sister bureaus, providing scientific input for decisions about the management of federal land.

But others point out that the survey does congressionally mandated work — including the earthquake hazards programme and water quality monitoring - that is of national importance well beyond the interior department. Local congresswoman Anna Eshoo (Democrat, California) reminded Babbitt of this wide constituency in a sharply worded letter expressing her concern.

Casadevall says that, "whatever's going to happen, it isn't going to happen quickly", and other officials promise that the costs of a move will be considered alongside its benefits. But many at Menlo Park remain anxious. One geophysicist says: "Even if this policy is abandoned next week, it would still be of concern to me that our leaders don't understand us."

LauraGarwin 